\title{
Quality Management Practice Influences Organizational Performance: A Case of a Vietnamese SME
}

\author{
Giang Ngo Tinh Nguyen ${ }^{1} \&$ Duong Tran Thuy Ninh ${ }^{1}$ \\ ${ }^{1}$ Becamex Business School, Eastern International University, Binh Duong, Vietnam \\ Correspondence: Giang Ngo Tinh Nguyen. Tel: 84-90-137-9912. E-mail: giang.nguyen@eiu.edu.vn
}

Received: March 12, 2017

Accepted: July 9, 2017 Online Published: August 25, 2017

doi:10.5539/ass.v13n9p33

URL: https://doi.org/10.5539/ass.v13n9p33

\begin{abstract}
Quality Management Practice (QMP) has been proven its positive impact on organizational performance and received significant attention in recent years. However, there is little or no studies on QMP and organizational performance in Vietnam, specifically in Binh Duong. This research concentrated on finding the degree to which five elements of QMP namely Leadership, Strategic Planning, Process Management, Human Resource Management and Customer Satisfaction influence organizational performance within the scope of a SME in Binh Duong, Vietnam. In this study, a survey was conducted involving internal human resources and external customers, resulting in a response rate of 100 percent. Data was collected from three different perspectives of managers, staff and customer to gain the best insight understanding. The results of the survey revealed that Strategic Planning, Human Resources Management and Customer Satisfaction take important role to play in increasing performance of this organization while the other fundamentals needs more improvement to fully implement QMP at the company. This research has the potential for further research to enhance the standards of QMP in Binh Duong area.
\end{abstract}

Keywords: quality management practices, organizational performance, SMEs, Vietnam

\section{Introduction}

\subsection{Background of the Research}

In contemporary society, small and medium scale firms must overcome many barriers to survive in the market (Rosli, 2012). The winners of the game are always the ones owning competitive advantage that differentiates them with the competitors (Davis, Aquilano, \& Chase, 2003). Business environment's characteristics currently are dynamic and uncertain. Hence, many organizations are under pressure to offer superior value to the customer and out-perform their rivals. Moreover, it is necessary to understand how the market is changing; thus, the firms will be able to response quickly to opportunities and challenges. For long-term success, they must seek approaches to enhance level of competitiveness and effectiveness (O'Mahony \& Garavan, 2012).

According to General Statistics Office of Vietnam, there were 316,941 SMEs in 2011, accounted for 97.6\% of the total enterprises. SME sector hold an important contribution in the national budget as the contribution increased by 2.6 times from 45 trillion VND to 177.8 trillion VND during the period of $2006-2011$ (General Statistics Office of Vietnam, 2013). Taking everything into consideration, the importance of SMEs in Vietnamese business structure is deniable as the SMEs deputize the backbone of Vietnamese economy; provide great percentage for state budget; labor jobs creation and encourage investment for social affair (Phan et al., 2015).

However, a large number of Vietnamese businesses, particularly small and medium enterprises (SMEs) only focus on "quick profit". They are losing the vision of long-term and strategic business or future development (Watanabe, 2003). That is the reason why many companies only focus on upgrading capacity and technology instead of towards to human resources improvement, sustainable development or international business standards. (Nguyen \& Robinson, 2015). To be specific, while U.S businesses spend 5\% of annual revenue to improve quality management and develop new products, that proportion at Vietnamese SMEs is just $0.3 \%$ (Dinh, 2010).

As SMEs are wondering whether implementation of quality management practice (QMP) leads to better performance for firms, there are a lot of researches revealed the positive impacts of QMP on organizational performance. Higher quality can contribute to cost reduction and productivity enhancement, which in turn leads to higher market position and sharpen the competitiveness of the company (Madi et al., 2008). Companies that 
apply quality management concentrate on exceeding customers' expectation and enhancing the process efficiency, which wil contribute to profit maximization and cost reduction. Moreover, higher quality implies higher customer satisfaction which maintains the competitive advantage of the firm (Madi et al., 2008). In short, QMP application can help SMEs to concentrate on their key market, utilize the material and human resources at a greater effective level and sharpen their competitive position according to the research of Temtime \& Solomon and Ahire \& Golhar (as cited in Gadenne \& Sharma, 2009).

\subsection{Research Objectives}

In order to answer the research question: "To what extent does each dimension of quality management practices affect organizational performance?", three primary objectives are addressed. Firstly, this research needs to figure out five important factors of QMP that had tight correlation with organizational performance. To understand the level of effect, the paper will examine the extent to which each factor impacts on the organizational performance at the company.

\subsection{Significance of the Study}

This study attempts to illustrate crucial elements of QMP in order to contribute to the enhancement of business performance. Moreover, it is unquestionable that Vietnam has a scarcity of management research. Although there has been a huge number of researches on QMP and its positive relationship with organizational performance on all over the world; the number of the influence of QMP on firm performance in Vietnam, particularly in Binh Duong's manufacturing industry is still insignificant. Thus, it is important to conduct this research to find out how QMP impacts on organizational performance to the context of a SME in Binh Duong. The research contribute as an example of how quality management can be examined in a typical Vietnamese SME, which in turn complete a set of valid and reliable operational measurement report of quality management for SMEs in general. Finally, it can contribute to an understanding of QMP in manufacturing SMEs.

\subsection{Literature Review}

\subsubsection{Quality Management Practice (QMP)}

Quality has become a tool that can help a company to achieve maximum benefit of continuous improvement. There are many ways of defining quality; Crosby defines quality as "conformance to requirements or specifications" (Crosby, 1979, p.7). Deming defined quality as "multidimensional to produce a product and/or deliver a service that meets the customer's expectations to ensure customer satisfaction" (Deming, 1986, p.54). Juran considers quality as "fitness for use" in which the degree of quality is earned by meet the customers' expectation in terms of design, availability, safety, conformance and use (Juran, 1988). Definition of quality from Feigenbaum's point of view is any product or service that meets the expectation from customers (Feigenbaum, 1991).

Quality management can be classified into hard and soft quality management practices. Hard quality management practices are technical instrument and techniques utilized as a part of quality management, while soft quality management practices cope with the administration of human, relationships and top management (Abdullah and Tarí, 2012).

\subsubsection{QMP and its relationship to Organizational Performance in SMEs}

According to Principles of Management, an organization is a group people gathered to work together to achieve one or multiple particular common goals (Koontz \& O'Donnell, 1968). In term of performance, it can be divided into two types which are individual-base performance and group performance. Individual-base performance means that you the work you have to do as a part of your daily job and group performance is how well members in the group accomplished both individual and group (Carpenter et al., 2012). Therefore, organizational performance can be understood as how successfully a team of individuals can fulfill a specific work for a common goal. In the research of the dimensionality of organizational performance and its implications for strategic management research, organizational performance is considered as multi-dimensions (Hamann et, 2013). However, in this paper, the organizational performance will be assessed based on following determinants naming efficient information flow, competitive position, market development, quality of the products, customer satisfaction (Demirbag, Lenny Koh, Tatoglu, \& Zaim, 2006).

Several experts in quality disciplines had stated that quality acts as a driver for productivity and performance (Deming, 1982; Juran, 1988). Previous studies have provided evidence that QMP positively impact on organizational performance. For example strongest influence in Flynn et al.'s research (Flynn et al., 1994) or positive relation in the study of Ahire et al., 1996; Kaynak, 2003; Lakhal et al., 2006; Powell, 1995; Samson \& Terziovski, 1999; Sila \& Ebrahimpour, 2005; Rao et al., 1999. 
Investigations from Abdullah and Tarí (2012); Duarte et al. (2011); and Klingenberg et al. (2013) have clearly confirmed that the relationship between QMP and organizational performance is not affected by the size of the business. QMP can lead to the increase of profitability and competitive advantage for both large and small firms (Kaushik et al., 2012). Although SMEs have limited potential in capital, market share and other resources, application of QMP in small firms is still possible because of "high employee involvement, multi-functional roles of the employees, and encouragement given to employee innovation" (Ahire \& Golhar, 1996).

\section{Research Methodology}

\subsection{Hypothesis Development and Reseach Framework}

\subsubsection{Hypothesis Development}

a. Leadership affects organizational performance.

The achievement of quality transformation in a business depends mainly on the commitment from top management (Pannirselvam \& Ferguson, 2001; Wilson \& Collier, 2000). Leadership is considered as a driver of QMP application by establishing goals and creating values; to achieve customer expectation satisfaction and organizational performance improvement (Ebrahimpour, 1988; Kaluarachchi, 2010). A crucial condition to implement QMP successfully in an organization is quality-oriented culture within that organization; and it has no possibility to change a business without a concentrated determination from management aimed at constantly enhancement, transparent communication and collaboration throughout the value chain all through the esteem chain (Abraham et al., 1999; Adebanjo \& Kehoe, 1999). In short, strong commitment form top management is a crucial factor in quality management which in turn leads to higher level of quality performance

b. Strategic Planning affects organizational performance.

Strategic planning is described as the way an organization make principal decisions to reinforce its business results and competitiveness (Seth \& Tripathi, 2005). This factor is significant affected by top management in strategic planning process (Krumwiede \& Charles, 2006). Strategic planning positively affects quality (Wilson \& Collier, 2000) as it allows the firm to generate clear goals and policy; and allocate resources to serve the quality goals (Sila \& Ebrahimpour, 2005). Strategic planning is aimed to sharpen the competitive advantage and remains a high priority for long-term development because of its requirements including quality-oriented objectives and approach; strategic development and positioning (Sila \& Ebrahimpour, 2005).

c. Process Management affects organizational performance.

According to Saraph et al., process management is considered as one of critical factors of quality management (Saraph et al., 1989). Process management involves the preventative step to QMP which means less reliance on inspection, more concentration on automated testing, employee self-inspection and required the clarity of work distribution (Saraph et al., 1989). Process management targets to reduce defects by using statistical process control or increasing quality level of production process (Flynn et al., 1995; Anderson et al., 1994) which in turn contributes to the enhancement of output quality and reduction in rework or waste (Anderson et al., 1994; Forza \& Flippini, 1998). This relationship was proven by Forza \& Flippini as process management directly and positively affects quality of products (Forza \& Flippini, 1998).

d. Human Resources Management affects organizational performance.

Two associated indicators of HRM are illustrated as employee training \& employee participation (Lakhal et al., 2006). Those two indicators are demonstrated as critical elements of Quality Management (Saraph et al., 1989). Firstly, quality-related training helps transform a normal employee into a productive worker and creative problem solver (Flynn et al., 1994). Secondly, employee participation is related to the open participants in quality decisions from employees; recognition and responsibility of employees towards quality issues; and continuous quality awareness of employees (Saraph et al., 1989). Those techniques consolidate the successful of QMP implementation based on the collaboration and coordination inside the business (Ho et al., 1999). In conclusion, to guarantee the continuous improvement mind set for employees, the organization must ensure the training program is available for every single individual (Anderson et al., 1995; Flynn et al., 1995).

e. Customer Satisfaction affects organizational performance.

Customer satisfaction is defined as how well a company's products or services can satisfy its customers' needs (Anderson et al., 1994). Therefore, effective customer relationship and ensure customer satisfaction are major factors that can enhance the competitive advantage of any enterprise. It is also a key component in quality management (Card \& Glass, 1990) and is accepted as a measure of quality (Hellens, 1997). According to Deming, quality should be targeted to meet the present and future need of consumers (Deming, 1986). Thus, a 
business can achieve high level of profitability through customer satisfaction by providing high quality product (Sila \& Ebrahimpour, 2005). Additionally, building long-term relationship with customers; increase the degree of customer survey and feedback utilization would be appropriate to enrich the satisfaction level (Ahire \& Golhar, 1996).

\subsubsection{Research Framework}

From the hypotheses explained above, the research framework is developed to clarify to what extent each dimension of quality management practices affects organizational performance

\section{Quality management dimensions}

1. Leadership

2. Strategic Planning

3. Process Management

4. Human Resources Management

5. Customer Satisfaction

\section{Organizational performance}

To measure to what extent these five dimensions affect performance of the organization, their associated indicators are illustrated as follows:

- Leadership: Efforts; Involvement \& Attitude to change (Das, Kumar, \& Kumar, 2011).

- Strategic planning: Quality mission, goals and policy; Strategy development \& Strategy deployment (Sila \& Ebrahimpour, 2005).

- Process management: Process control (Baird et al., 2011).

- Human Resources Management: Employee training \& Employee participation (Lakhal et al., 2006).

- Customer satisfaction: The frequency of contacts with the customer\& Handling of customer's inquiries (Seth \& Tripathi, 2005).

\subsection{Research Methodology}

\subsubsection{Research Population and Sample Size}

As the company is a SME, the total employees are 46 people, including managerial position and staff. In terms of its major customers, the questionnaire will be delivered to the top 10 wholesalers. Thus, the population is 56 people. In terms of a sample, it is expected that $100 \%$ of the participants will respond. In another word, the population is the sample.

\subsubsection{Methodology}

Case study methodology is implemented in this research. A case study can contribute to new theory building (Rahim \& Bask, 2003) or information discovery which many not have been explained in previous research (Gray, 1998). Case study research is exclusively (Gray, 1998) as it enables to take advantage from both qualitative and quantitative approach (Simons, 2009).

There are three types of case studies which are exploratory, descriptive and explanatory (Yin, 2003). Based on the purpose of the study is to explain a causative relationship between QMP and organizational performance, explanatory case study is chosen as the main methodology.

In short, the case study is used for this research for three reasons. Firstly, a greater in-depth analysis could be obtained. Secondly, it is flexible to assess to reliability, validity and primary of data (Hoskisson et al, 2000). Finally, the case is investigated a real event at a company; hence, the study will provide a high level of validity result (Voss et al., 2002)

\subsubsection{Measurement structure}

In this research, a 1-5 Likert scale - ranging from Strongly agree (1) to Strongly disagree (5) - is used to analyze the result of the survey. All three versions had the same Likert Scale distribution to ensure consistency of data and the ease of analysis in the next chapter.

As the questionnaire was originally written in English, a decision to translate it into Vietnamese was made to make it clear for every respondent because the level of English reading comprehension is quite low. There will be three versions of the questionnaire list. 
- Questionnaire for manager: the questionnaire list is designed to consist of 21 questions. The structure is first two questions for general information, the next five questions for Organizational Performance assessment (based on the survey instrument of Awoku, 2012) and the last 14 questions for information of causal relationship between QMP and organizational performance (based on the survey instrument of Das, Kumar, \& Kumar, 2011; Sila \& Ebrahimpour, 2005; Baird et al., 2011)

- Questionnaire for staff: the questionnaire list is designed to consist of 12 questions. The structure is first two questions for general information, the next five questions for organizational performance assessment (based on the survey instrument of Awoku, 2012) and the last five questions for information of causal relationship between QMP and organizational performance (based on the survey instrument of Lakhal et al., 2006)

- Questionnaire for customer: the questionnaire list is designed to consist of 11 questions. The structure is first two questions for general information, the next five questions for organizational performance assessment (based on the survey instrument of Awoku, 2012) and the last four questions for information of causal relationship between QMP and organizational performance (based on the survey instrument of Seth \& Tripathi, 2005)

Consequently, primary data is collected through an online survey. The unit of analysis will be divided into three types of respondents including managers, staff and customers. In terms of secondary data, academic materials books, journals and articles - is conscientiously examined and gathered to support for the results found.

\subsubsection{Research responses}

A total 56 return emails were received indicated the overall rate of $100 \%$. As the company is small size enterprise, the population is also limited. Thus, the greater number of respondent, the better the results. To achieve that response rate, a week after the first email, a set of reminder email was sent to the participants to ensure the survey is completed and sent back to the researcher.

\subsubsection{Data analysis techniques}

Statistical Product and Services Solutions (SPSS) software was chosen to analyze the data in this research for the following reason. Firstly, basic function can be accessed fast and easily such as descriptive statistics (e.g. mean, standard deviation or median). Secondly, SPSS offers a wide range of both basic and complex graphs, contingency tables for example. Finally, statistical tests are easier to find compared with undiversified range of statistical tests in Excel software (Understanding the benefits, 2010).

The process of analysis includes four steps. At first, the Cronbach's Alpha was found out to test the reliability of six variables. After that, the Exploratory Factor Analysis was conducted to identify the structure of the relationship between two types of variables. Next, the correlation between dependent and independent variables was tested. Finally, the Multiple Regression was utilized to perform the relationship of independent variables with dependent variable.

\section{Data Analysis and Results}

\subsection{Descriptive Data Analysis}

\subsubsection{Five dimensions of QMP and Organizational Performance}

After the SPSS analysis process, the results are presented in three tables below. Those ones reflect the descriptive data of manager, staff and customers' perspectives in particular elements of QMP including Leadership, Strategic Planning, Process Management, Human Resources Management and Customer Satisfaction towards Organizational Performance. The values in the table consist of minimum, maximum, mean and standard deviation. The variables are evaluated by the Likert scale ranging from 1 to 5 with $1=$ Strongly Agree and $5=$ Strongly Disagree.

a. Managers' perspective

Managers' questions related to three dimensions which are Leadership (LD1 - LD4), Strategic Planning (ST1 ST5) and Process Management (PM1-PM5).

Table 1. Descriptive analysis for Managers' perspective

\begin{tabular}{cccccc}
\hline & N & Minimum & Maximum & Mean & Std. Deviation \\
\hline LD1 & 4 & 2 & 5 & 3.50 & 1.291 \\
LD2 & 4 & 3 & 5 & 3.75 & .957 \\
LD3 & 4 & 3 & 5 & 3.75 & .957 \\
LD4 & 4 & 4 & 5 & 4.25 & .500 \\
\hline
\end{tabular}




\begin{tabular}{llllll}
\hline ST1 & 4 & 3 & 5 & 4.00 & .816 \\
ST2 & 4 & 3 & 4 & 3.75 & .500 \\
ST3 & 4 & 3 & 5 & 3.75 & .957 \\
ST4 & 4 & 3 & 5 & 4.00 & .816 \\
ST5 & 4 & 3 & 4 & 3.75 & .500 \\
PM1 & 4 & 2 & 5.25 & 3.25 & .957 \\
PM2 & 4 & 2 & 4 & 3.75 & .957 \\
PM3 & 4 & 3 & 4.00 & .000 \\
PM4 & 4 & 4 & 4 & 3.50 & .577 \\
PM5 & 4 & 3 & & & \\
\hline
\end{tabular}

The table above shown the results that the maximum scale rated for each question is 4 or 5 and the minimum one is 2 . Among them, the question "A manager arranges adequate resources for employee education and training" reached the highest Mean which is 4.25 . It could be understood that the ability of manager to set up quality training and educating for employees is crucial to fully implement the QMP. However, there are two questions ranked at the bottom Mean which are "Inspection, review or checking of work is automated" and "Production schedule/work distribution is stable". This demonstrates the least importance of those factors to QMP.

b. Staff's perspective

Employees are the one to help investigate about Human Resource Management factor (HRM1 - HRM5).

Table 2. Descriptive analysis for Staff's perspective

\begin{tabular}{cccccc}
\hline & $\mathrm{N}$ & Minimum & Maximum & Mean & Std. Deviation \\
\hline HR1 & 42 & 1.0 & 5.0 & 3.905 & 1.1001 \\
HR2 & 42 & 2.0 & 5.0 & 3.762 & .8500 \\
HR3 & 42 & 1.0 & 5.0 & 3.381 & .9866 \\
HR4 & 42 & 1.0 & 5.0 & 3.690 & 1.0238 \\
HR5 & 42 & 1.0 & 5.0 & 3.262 & .9892
\end{tabular}

Valid N (listwise) $\quad 42$

The result shown that the minimum scale rated at 1 or 2 and the highest one is 5 . With mean of 3.905, the question "I am received continuous training" was ranked at the highest. It means the company is doing well with the training course related to continuous improvement for the employees.

c. Customers' perspective

Customer Satisfaction will be examined by Customers (CS1 - CS4)

Table 3. Descriptive analysis for Customers' perspective

\begin{tabular}{cccccc}
\hline & $\mathrm{N}$ & Minimum & Maximum & Mean & Std. Deviation \\
\hline CS1 & 10 & 1.0 & 4.0 & 2.800 & .9189 \\
CS2 & 10 & 2.0 & 5.0 & 3.700 & .8233 \\
CS3 & 10 & 2.0 & 5.0 & 3.700 & .9487 \\
CS4 & 10 & 1.0 & 4.0 & 3.000 & .9428 \\
Valid N (listwise) & 10 & & & &
\end{tabular}

Obviously, it could be seen that the maximum scale rated for each question is 4 or 5 and the smallest is the combination of 1 and 2. The highest mean which is 3.7 is achieved by two questions including "My satisfaction is collected and evaluated" and "I received the enthusiastic support from the company's employees".

d. Organizational Performance

This dependent variable is reviewed by all three types of respondents. It includes 5 questions ranging from OP1 to OP5.

Table 4. Descriptive analysis for Organizational Performance

\begin{tabular}{cccccc}
\hline & $\mathrm{N}$ & Minimum & Maximum & Mean & Std. Deviation \\
\hline OP1 & 56 & 2.0 & 5.0 & 3.482 & .8737 \\
OP2 & 56 & 1.0 & 5.0 & 3.357 & .9230 \\
\hline
\end{tabular}




\begin{tabular}{cccccc}
\hline OP3 & 56 & 1.0 & 5.0 & 3.268 & .9628 \\
OP4 & 56 & 1.0 & 5.0 & 3.661 & 1.0665 \\
OP5 & 56 & 1.0 & 5.0 & 3.518 & 1.0786 \\
Valid N (listwise) & 56 & & & & \\
\hline
\end{tabular}

The information in the table above illustrated the minimum scale is 1 or 2 and the maximum one is 5. Among them, the question "The organization provides high quality products" received the highest agreement from three types of respondent including managers, staff and customers while the one at the bottom is "The organization offers transparent sales plan and long-term development policy".

\subsection{Data Analysis Procedure}

\subsubsection{Cronbach's alpha}

Cronbach's alpha will let the researchers know how well the survey have been designed to accurately measure the variable (Tavakol \& Dennick, 2011). A rule for Likert scale questions is:

- $\alpha \geq 0.9$ : Excellent

- $0.9>\alpha \geq 0.8$ : Good

- $0.8>\alpha \geq 0.7$ : Acceptable

- $0.7>\alpha \geq 0.6$ : Questionable

- $0.6>\alpha \geq 0.5$ : Poor

- $0.5>\alpha$ : Unacceptable

Table 5. Cronbach's Alpha value

\begin{tabular}{ccc}
\hline & Cronbach's Alpha & No of Items \\
\hline LEADERSHIP (LD) & .902 & 4 \\
STRATEGIC PLANNING (ST) & .889 & 4 \\
PROCESS MANAGEMENT (PM) & .917 & 3 \\
HUMAN RESOURCE MANAGEMENT (HRM) & .834 & 4 \\
CUSTOMER SATISFACTION (CS) & .890 & 4 \\
ORGANIZATIONAL PERFORMANCE (OP) & .823 & 2 \\
\hline
\end{tabular}

In a situation that the case study is a new concept or new in the context of the research, the Cronbach's alpha coefficient greater than 0.6 is accepted (Chu \& Trong, 2008). Therefore, all variables are reliable to go through the next section of data analysis for demonstrating the result of this research.

a. Leadership

Table 6. Cronbach's Alpha value of Leadership

\begin{tabular}{ccccc}
\hline & $\begin{array}{c}\text { Scale Mean if Item } \\
\text { Deleted }\end{array}$ & $\begin{array}{c}\text { Scale Variance if Item } \\
\text { Deleted }\end{array}$ & $\begin{array}{c}\text { Corrected Item-Total } \\
\text { Correlation }\end{array}$ & $\begin{array}{c}\text { Cronbach's Alpha if Item } \\
\text { Deleted }\end{array}$ \\
LD1 & 11.75 & 4.917 & .873 & .864 \\
LD2 & 11.50 & 7.000 & .724 & .893 \\
LD3 & 11.50 & 6.333 & .899 & .829 \\
LD4 & 11.00 & 8.667 & .906 & .894 \\
\hline
\end{tabular}

The table above illustrates the reliability value of Leadership element. Four indicators of Leadership - LD1, LD2, LD3, and LD4's total correlation values are over 0.7 with no item eliminated.

Therefore, accept $\mathrm{H}_{\mathrm{A} 1}$ : Leadership affects organizational performance.

b. Strategic Planning

Table 7. Cronbach's Alpha value of Strategic Planning

\begin{tabular}{ccccc}
\hline & Scale Mean if Item Deleted & $\begin{array}{c}\text { Scale Variance if Item } \\
\text { Deleted }\end{array}$ & $\begin{array}{c}\text { Corrected Item-Total } \\
\text { Correlation }\end{array}$ & $\begin{array}{c}\text { Cronbach's Alpha if Item } \\
\text { Deleted }\end{array}$ \\
\hline ST2 & 11.50 & 4.333 & .801 & .865 \\
ST3 & 11.50 & 3.000 & .704 & .917 \\
ST4 & 11.25 & 2.917 & .956 & .771 \\
ST5 & 11.50 & 4.333 & .801 & .865 \\
\hline
\end{tabular}


Table 7 describes the reliability value of Strategic Planning factor. After the first test, the value "Cronbach's Alpha if item deleted" of ST1 was higher than total value. Hence, it was rejected in the second test. The value of ST2, ST3, ST4 and ST5 are over 0.7 .

Therefore, accept $\mathrm{H}_{\mathrm{A} 2}$ : Strategic Planning affects organizational performance.

c. Process Management

Table 8. Cronbach's Alpha value of Process Management

\begin{tabular}{ccccc}
\hline & $\begin{array}{c}\text { Scale Mean if Item } \\
\text { Deleted }\end{array}$ & $\begin{array}{c}\text { Scale Variance if Item } \\
\text { Deleted }\end{array}$ & $\begin{array}{c}\text { Corrected Item-Total } \\
\text { Correlation }\end{array}$ & $\begin{array}{c}\text { Cronbach's Alpha if Item } \\
\text { Deleted }\end{array}$ \\
\hline PM1 & 11.25 & 2.250 & 1.000 & .667 \\
PM3 & 10.75 & 4.250 & .971 & .588 \\
PM5 & 11.00 & 6.000 & .943 & .708 \\
\hline
\end{tabular}

Table 8 indicates the reliability value of Process Management fundamental. In the second test, the value of PM2 and PM4 were rejected to increase the total value. The value of PM1, PM3 and PM5 are all higher than 0.7 as required.

Therefore, accept $\mathrm{H}_{\mathrm{A} 3}$ : Process Management affects organizational performance.

d. Human Resource Management

Table 9. Cronbach's Alpha value of Human Resource Management

\begin{tabular}{ccccc}
\hline & $\begin{array}{c}\text { Scale Mean if Item } \\
\text { Deleted }\end{array}$ & $\begin{array}{c}\text { Scale Variance if Item } \\
\text { Deleted }\end{array}$ & $\begin{array}{c}\text { Corrected Item-Total } \\
\text { Correlation }\end{array}$ & $\begin{array}{c}\text { Cronbach's Alpha if Item } \\
\text { Deleted }\end{array}$ \\
\hline HR2 & 10.333 & 5.984 & .778 & .748 \\
HR3 & 10.714 & 6.063 & .598 & .820 \\
HR4 & 10.405 & 5.564 & .689 & .779 \\
HR5 & 10.833 & 5.996 & .613 & .814 \\
\hline
\end{tabular}

Table 9 depicts the reliability value of Human Resource Management item. Because the HR1's value was higher than actual Cronbach's Alpha, it then was removed. At the end, the value of HR2, HR3, HR4 and HR5 are considered as a quite good source of data since they are bigger than 0.5 .

Therefore, accept $\mathrm{H}_{\mathrm{A} 4}$ : Human Resource Management affects organizational performance.

e. Customer Satisfaction

Table 10. Cronbach's Alpha value of Customer Satisfaction

\begin{tabular}{ccccc}
\hline Scale Mean if Item Deleted & $\begin{array}{c}\text { Scale Variance if Item } \\
\text { Deleted }\end{array}$ & $\begin{array}{c}\text { Corrected Item-Total } \\
\text { Correlation }\end{array}$ & $\begin{array}{c}\text { Cronbach's Alpha if Item } \\
\text { Deleted }\end{array}$ \\
\hline CS1 & 10.400 & 5.600 & .807 & .839 \\
CS2 & 9.500 & 6.056 & .795 & .848 \\
CS3 & 9.500 & 5.611 & .766 & .855 \\
CS4 & 10.200 & 5.956 & .676 & .890 \\
\hline
\end{tabular}

Table 10 defines the reliability value of Customer Satisfaction component. The result shown that each question belonged to Customer Satisfaction section is meet the requirement which is higher than 0.6 without any item eliminated.

Therefore, accept $\mathrm{H}_{\mathrm{A} 5}$ : Customer Satisfaction affects organizational performance.

e. Organizational Performance

Table 11. Cronbach's Alpha value of Organizational Performance

\begin{tabular}{ccccc}
\hline & Scale Mean if Item Deleted & $\begin{array}{c}\text { Scale Variance if Item } \\
\text { Deleted }\end{array}$ & $\begin{array}{c}\text { Corrected Item-Total } \\
\text { Correlation }\end{array}$ & $\begin{array}{c}\text { Cronbach's Alpha if Item } \\
\text { Deleted }\end{array}$ \\
OP1 & 3.518 & 1.163 & .714 &. \\
OP5 & 3.482 & .763 & .714 &. \\
\hline
\end{tabular}

Finally, Table 11 delineates the reliability value of Organizational Performance variable. As the value of OP2, OP3 and OP4 were lower than 0.5 , they were eliminated in the second process. Thus, the value of OP1 and OP5 are accepted as their Corrected Item-Total Correlation values excess 0.7 . 


\subsubsection{Exploratory factor analysis}

Exploratory factor analysis (EFA) is a statistical technique that is used to reduce data to a smaller set of summary variables but still contain the original information and aimed to explore relationships among the variables (Yong $\&$ Pearce, 2013). When scales are developed, EFA can be used to test the new scale. Then, it can confirm factor analysis to see whether the factor structure in that new sample is validated or not (Osborne\& Fitzpatrick, 2012).

According to (Hair et al., 1998), Factor loading is an indicator to ensure the practical significance of EFA:

- Factor loading $>0.3$ is considered at minimum standard.

- Factor loading $>0.4$ is considered important.

- Factor loading $>0.5$ are considered to have practical significance.

Table 12. Exploratory factor analysis

\begin{tabular}{ccr}
\hline & Kaiser-Meyer-Olkin Measure of Sampling Adequacy. & Sig. \\
\hline HUMAN RESOURCE MANAGEMENT (HRM) & .762 & .000 \\
CUSTOMER SATISFACTION (CS) & .656 & .002 \\
\hline
\end{tabular}

The table above shows that Kaiser-Meyer-Olkin ratio of Human Resources Management and Customer Satisfaction is greater than 0.5 and the Sig ratio is less than 0.05 . This means that the variables are correlated with each other generally. However, SPSS software cannot run the Exploratory factor analysis for Leadership, Strategic Planning and Process Management fundamentals because of the small size of data.

\subsubsection{Correlation Analysis}

Correlation Analysis is the most commonly used statistical tool which used to determine how strong a relationship between two variables is present if it exist. The correlation is measured by Coefficient of Correlation (Hays, 1985). It can range from -1.00 to +1.00 . While -1.00 means a completely negative relationship - when the value of one variable goes up, the other follows a contrast trend, +1.00 means a complete positive correlation when the value of one a variable increase, the other also increase. When there is no relationship between the tested variables, the value will be 0.00 (Rodgers \& Nicewander, 1988).

Table 13. Pearson's Correlation Value

\begin{tabular}{cccc}
\hline & Pearson Correlation & Sig. (2-tailed) & $\mathrm{N}$ \\
\hline LEADERSHIP (LD) & .754 & .246 & 4 \\
STRATEGIC PLANNING (ST) & $.985^{*}$ & .015 & 4 \\
PROCESS MANAGEMENT (PM) & .734 & .266 & 4 \\
HUMAN RESOURCE MANAGEMENT (HRM) & $.766^{* *}$ & .000 & 42 \\
CUSTOMER SATISFACTION (CS) & $.652^{*}$ & .041 & 10 \\
\hline
\end{tabular}

*. Correlation is significant at the 0.05 level (2-tailed).

**. Correlation is significant at the 0.01 level (2-tailed).

From table 13, the Pearson's correlation value delineates the Organizational Performance has a relationship with three independent variables including Strategic Planning, Human Resource Management (HRM) and Customer Satisfaction. On the other hand, Leadership and Process Management have no influence on Organizational Performance at the examized SME. Overall, these figures were good to show the positive relationships between dependent variable and independent variables. As a result:

$\mathbf{H}_{\mathbf{A} 1}$ : "Leadership affects organizational performance" was not supported by data.

$\mathbf{H}_{\mathrm{A} 2}$ : "Strategic Planning affects organizational performance" was supported by data.

$\mathbf{H}_{\mathbf{A} 3}$ : "Process Management affects organizational performance" was not supported by data.

$\mathbf{H}_{\mathbf{A} 4}$ : "Human Resources Management affects organizational performance" was supported by data.

$\mathbf{H}_{\mathrm{A} 5}$ : "Customer Satisfaction affects organizational performance" was supported by data.

\subsubsection{Multiple Regressions}

Multiple Regression is a statistical tool used to analyze the relationship between a dependent variable and multiple independent variables (Gibson\& Jowett, 1957). In general, the form multiple regression equation is given by: $\mathbf{Y}=\mathbf{A}+\mathbf{B}_{\mathbf{1}} \mathbf{X}_{\mathbf{1}}+\mathbf{B}_{\mathbf{2}} \mathbf{X}_{\mathbf{2}}+\ldots \ldots \ldots \ldots \ldots \ldots \ldots . . . \ldots \mathbf{B}_{\mathbf{k}} \mathbf{X}_{\mathbf{k}}($ Kim \& Kohout, 1975).

Based on the Pearson's Correlation Value above, the Multiple Regression is processed with three factors 
consisting of Strategic Planning, Human Resource Management (HRM) and Customer Satisfaction. Also, because of the non-correlated relationship, Leadership and Process Management will be eliminated in this analysis.

Table 14. Regression for Strategic Planning factor

\begin{tabular}{ccccc}
\hline Model & R & R Square & Adjusted R Square & Std. Error of the Estimate \\
\hline 1 & $.985^{\text {a }}$ & .971 & .956 & .1910 \\
\hline
\end{tabular}

a. Predictors: (Constant), ST

b. Dependent Variable: OP-Manager

Table 15. Coefficients Statistics for Strategic Planning factor

\begin{tabular}{|c|c|c|c|c|c|c|c|}
\hline \multirow{2}{*}{ Model } & \multicolumn{2}{|c|}{ Unstandardized Coefficients } & \multirow{2}{*}{$\frac{\text { Standardized Coefficients }}{\text { Beta }}$} & \multirow{2}{*}{$\mathrm{t}$} & \multirow{2}{*}{ Sig. } & \multicolumn{2}{|c|}{ Collinearity Statistics } \\
\hline & B & Std. Error & & & & Tolerance & VIF \\
\hline (Constant) & -2.662 & .777 & & -3.426 & .076 & & \\
\hline ST & 1.626 & .200 & .985 & 8.123 & .015 & 1.000 & 1.000 \\
\hline
\end{tabular}

a. Dependent Variable: OP-Manager

An equation which illustrates the relationship between independent and dependent variables is as followed: OP-Manager $=\beta_{0}+\beta_{1}$ ST. Where:

OP-Manager is denoted as Organizational Performance viewed by Manager (Dependent factor)

$\mathrm{ST}$ is denoted as Strategic Planning (Independent factor)

Constant $=-2.662$

The equation is developed as: OP-Manager $=-2.662+1.626 \mathrm{x} \mathrm{ST}$

Table 16. Regression for Human Resource Management factor

\begin{tabular}{ccccc}
\hline Model & $\mathrm{R}$ & R Square & Adjusted R Square & Std. Error of the Estimate \\
\hline 1 & $.766^{\mathrm{a}}$ & .586 & .576 & .4925 \\
\hline
\end{tabular}

a. Predictors: (Constant), HRM

b. Dependent Variable: OP-Staff

Table 17. Coefficients Statistics for Human Resource Management factor

\begin{tabular}{|c|c|c|c|c|c|c|c|c|}
\hline & \multirow{2}{*}{ Model } & \multicolumn{2}{|c|}{ Unstandardized Coefficients } & \multirow{2}{*}{$\frac{\text { Standardized Coefficients }}{\text { Beta }}$} & \multirow{2}{*}{$\mathrm{t}$} & \multirow{2}{*}{ Sig. } & \multicolumn{2}{|c|}{ Collinearity Statistics } \\
\hline & & B & Std. Error & & & & Tolerance & VIF \\
\hline \multirow{2}{*}{1} & (Constant) & .699 & .372 & & 1.880 & .067 & & \\
\hline & HRM & .761 & .101 & .766 & 7.532 & .000 & 1.000 & 1.000 \\
\hline
\end{tabular}

a. Dependent Variable: OP-Staff

An equation which illustrates the relationship between independent and dependent variables is as followed: OPStaff $=\beta_{0}+\beta_{1}$ HRM. Where:

OP- Staff is denoted as Organizational Performance viewed by Staff (Dependent factor)

HRM is denoted as Human Resource Management (Independent factor)

Constant $=0.699$

The equation is developed as below: OP-Staff $=\mathbf{0 . 6 9 9}+\mathbf{0 . 7 6 1} \times$ HRM

Table 18. Regression for Customer Satisfaction factor

\begin{tabular}{ccccc}
\hline Model & $\mathrm{R}$ & R Square & Adjusted R Square & Std. Error of the Estimate \\
\hline 1 & $.652^{\mathrm{a}}$ & .425 & .353 & .4627 \\
\hline
\end{tabular}

a. Predictors: (Constant), CS

b. Dependent Variable: OP-Customer

Table 19. Coefficients Statistics for Customer Satisfaction factor

\begin{tabular}{|c|c|c|c|c|c|c|c|c|}
\hline & \multirow{2}{*}{ Model } & \multicolumn{2}{|c|}{ Unstandardized Coefficients } & \multirow{2}{*}{$\frac{\text { Standardized Coefficients }}{\text { Beta }}$} & \multirow{2}{*}{$\mathrm{t}$} & \multirow{2}{*}{ Sig. } & \multicolumn{2}{|c|}{ Collinearity Statistics } \\
\hline & & $\mathrm{B}$ & Std. Error & & & & Tolerance & VIF \\
\hline \multirow{2}{*}{1} & (Constant) & 1.913 & .662 & & 2.891 & .020 & & \\
\hline & $\mathrm{CS}$ & .475 & .196 & .652 & 2.430 & .041 & 1.000 & 1.000 \\
\hline
\end{tabular}


a. Dependent Variable: OP-Customer

An equation which illustrates the relationship between independent and dependent variables is as followed: OP-Customer $=\beta_{0}+\beta_{1} \mathrm{CS}$. Where:

OP-Customer is denoted as Organizational Performance viewed by Customers (Dependent factor)

$\mathrm{CS}$ is denoted as Customer Satisfaction (Independent factor)

Constant $=1.913$

The equation is developed as below: OP-Customer $=\mathbf{1 . 9 1 3}+\mathbf{0 . 4 7 5} \times \mathbf{C S}$

From tables above, the regression summary has shown that $97.1 \%$ of Strategic Planning fundamental, $57.6 \%$ of Human Resource Management (HRM) element and 42.5\% of Customer Satisfaction factor contributed to the Organizational Performance which is quite acceptable figures. Moreover, as the Sig. value of HRM is smaller than $5 \%$, those three items are statistically significant.

Moreover, as the Organizational Performance is viewed from three different perspectives of three different types of respondents, there are three equations to illustrate the relationship of Strategic Planning, Human Resource Management and Customer Satisfaction towards Organizational Performance.

In regression analysis, beta is a key indicator to determine whether independent variables have a strong impact on the dependent variable or not. The higher value of beta, the higher level of influences of independent variables (Freedman, 2005). Based on that, it is concluded that Strategic Planning the strongest influence on Organizational Performance with $\beta=0.985$ while Customer Satisfaction has the least impact with $\beta=0.652$.

\section{Discussions and Recommendations}

The analysis reflects that there is a relationship between and Organizational Performance and three dimensions of QMP which are Strategic Planning, Human Resources Management and Customer Satisfaction. While the other two dimensions which are Leadership and Process Management have no impact on Organizational Performance in this specific case. In summary, based on the result after data analysis process, if the company wants to increase the Organizational Performance, it should focus to improve the productivity of each individual within the company and continue organizing training course to sharpen the continuous improvement mindset of the employees. Based on this, the company not only can gain more profit but also can provide a future vision for the whole organization which is sustainable development. The findings also show the importance of Strategic Planning. It includes both short-term and long-term objectives from the overall goals of improvement strategy. In addition, Strategic Planning is a reflection of vision from top management in terms of company's grand strategies and resource allocation. Finally, a strong focus on Customer Satisfaction is obvious since the improvement of QMP begins from customer viewpoint.

After the data analysis for the company, the result for influence of Leadership and Process Management on Organizational Performance is not significant as expectation. However, the evidence of positive relationship among those fundamentals and Organizational Performance is already proven in previous studies. Therefore, the company still needs to pay attention to Leadership and Process Management to fully enhance performance of the firm.

As Leadership is directly related to both Strategic Planning and HRM. Effective leadership from top management is unquestionably crucial in the process of QMP implementation. Companies with high top management competencies can execute quality management more effectively and be able to provide product at higher quality level to customers (Das, Kumar, \& Kumar, 2011). Process Management is an indicator that will contribute to increase the productivity of employees as it reduces defects during the production stage which will in turn save time and effort on checking the finished goods (Pilkington, 1996).

In conclusion, the findings shown in this study support the importance of QMP in every kind of organization, regardless the size or industry. Therefore, manager of SMEs need to realize that QMP should be implemented comprehensively rather than on a piecemeal basis to gain the full potential of QMP.

\section{Acknowledgments}

We would like to thank the support from managers, staff and whole sallers of the examined enterprise, but due to the confidential purposes, the company's name is not revealed. Without the passionate participation and input, the validation survey could not have been successfully conducted.

\section{References}

Abdullah, M. M. B., \& Tarí, J. J. (2012). The influence of soft and hard quality management practices on 
$\begin{array}{lllll}\text { performance. Asia Pacific } & \text { Management } & \text { Review, } & \text { 17(2), }\end{array}$ http://dx.doi.org/10.1108/17542730810898412

Abraham, M., Crawford, J., \& Fisher, T. (1999). Key factors predicting effectiveness of cultural change and improved productivity in implementing total quality management. International Journal of Quality \& Reliability Management, 16(2), 112-132. http://dx.doi.org/10.1108/02656719910239910

Adebanjo, D., \& Kehoe, D. (1999). An investigation of quality culture development in UK industry. International Journal of Operations \& Production Management, 19(7), 633-650. http://dx.doi.org/10.1108/01443579910271656

Ahire, L., \& Golhar, Y. (1996). Quality management in large vs small firms. Journal of Small Business Management, 34(2), 1-13.

Anderson, J., \& Rungtusanatham, M. (1994). A theory of quality management underlying the Deming management method. Academy of Management Review, 19(3), 472-509. http://dx.doi.org/10.5465/amr.1994.9412271808

Anderson, J. C., Rungtusanatham, M., Schroeder, R. G., \& Devaraj, S. (1995). A Path Analytic Model of a Theory of Quality Management Underlying the Deming Management Method: Preliminary Empirical Findings. Decisions Sciences, 26(5), 637-658. http://dx.doi.org/10.1111/j.1540-5915.1995.tb01444.x

Awoku, R. Yetunde-Abiodun. (2012). An Empirical Study On Quality Management Practices, Organization Performance and Suppliers' Selection In Southern Minnesota Manufacturing Firms. All Theses, Dissertations, and Other Capstone Projects. Paper 174.

Baird, K., Jia Hu, K., \& Reeve, R. (2011). The relationships between organizational culture, total quality management practices and operational performance. International Journal Of Operations \& Production Management, 31(7), 789-814. http://dx.doi.org/10.1108/01443571111144850

Card, D., \& Glass, R. (1990). Measuring software design quality (1st ed.). Englewood Cliffs, N.J.: Prentice Hall.

Carpenter, M., Bauer, T., \& Erdogan, B. (2012). Management Principles. Retrieved from http://2012books.lardbucket.org/

Chu, N., \& Trong, H. (2008). Research data analysis by SPSS. Hong Duc Publishing House.

Cresswell, J. W. (1998). Qualitative inquiry and Research design: Choosing among five traditions. Thousand Oaks, CA: Sage.

Crosby, P. (1979). Quality Is Free. New York, And Mentor.

Das, A., Kumar, V., \& Kumar, U. (2011). The role of leadership competencies for implementing TQM: An empirical study in Thai manufacturing industry. International Journal of Quality \& Reliability Management, 28(2), 195-219. http://dx.doi.org/10.1108/02656711111101755

Davis, M., Aquilano, N., \& Chase, R. (2003). Fundamentals of operations management (1st ed.). Boston: McGraw-Hill/Irwin.

Deming, W. E. (1982). Quality, productivity, and competitive position (1st ed.). Cambridge, MA: Massachusetts Institute of Technology, Center for Advanced Engineering Study.

Deming, W. E. (1986). Out of the Crisis. MIT Press: Cambridge, MA.

Demirbag, M., Lenny Koh, S., Tatoglu, E., \& Zaim, S. (2006). TQM and market orientation's impact on SMEs'

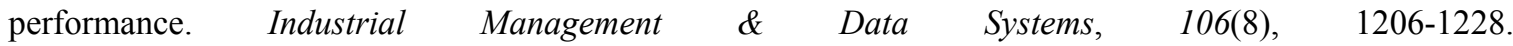
http://dx.doi.org/10.1108/02635570610710836

Dinh, N. K. (2010). Quality Management (2nd ed.). Financial Publishing House.

Duarte, M., Brito, L., Serio D., \& Martins, S. (2011). Operational practices and financial performance: An empirical analysis of Brazilian manufacturing companies. Brazilian Administration Review, 8, 395-411.

Ebrahimpour, M. (1988). An Empirical Study of American and Japanese Approaches to Quality Management in the United States. International Journal of Quality \& Reliability Management, 5(5), 5-24. http://dx.doi.org/10.1108/eb002915

Feigenbaum, A. V. (1991). Total Quality Control. McGraw-Hill, Inc., New York, NY.

Flynn, B., Schroeder, R., \& Sakakibara, S. (1994). A framework for quality management research and an associated measurement instrument. Journal of Operations Management, 11(4), 339-366. 
http://dx.doi.org/10.1016/s0272-6963(97)90004-8

Flynn, B., Schroeder, R., \& Sakakibara, S. (1995). The Impact of Quality Management Practices on Performance and Competitive Advantage. Decision Sciences, 26(5), 659-691. http://dx.doi.org/10.1111/j.1540-5915.1995.tb01445.x

Forza, C., \& Filippini, R. (1998). TQM impact on quality conformance and customer satisfaction: A causal model. International Journal of Production Economics, 55(1), 1-20. http://dx.doi.org/10.1016/s0925-5273(98)00007-3

Freedman, D. (2005). Statistical models (1st ed.). Cambridge: Cambridge University Press.

Gadenne, D., \& Sharma, B. (2009). An investigation of the hard and soft quality management factors of Australian SMEs and their association with firm performance. International Journal Of Quality \& Reliability Management, 26(9), 865-880. http://dx.doi.org/10.1108/02656710910995064

General Statistics Office of Vietnam. (2013). Small and medium enterprises in the period of 2006 - 2011. Statistical Publishing House.

Gray, M. (1998). Introducing single case study research design: An overview. Nurse Researcher, 5(4), 15-24. http://dx.doi.org/10.7748/nr1998.07.5.4.15.c6070

Hamann, P. M., Schiemann, F., Bellora, L., \& Guenther, T. W. (2013). Exploring the Dimensions of Organizational Performance: A Construct Validity Study. Organizational Research Method, 16(1).

Hays, W. (1985). An Introduction to Linear Regression and Correlation (2nd ed.). Psyccritiques, 30(10). http://dx.doi.org/10.1037/023287

Ho, D., Duffy, V., \& Shih, H. (1999). An empirical analysis of effective TQM implementation in the Hong Kong electronics manufacturing industry. Human Factors and Ergonomics in Manufacturing, 9(1), 1-25. http://dx.doi.org/10.1002/(sici)1520-6564(199924)9:1<1::aid-hfm1>3.3.co;2-c

Hoskisson, R., Eden, L., Lau, C. \& Wright, M. (2000). Strategy in emerging economies. The Academy of Management Journal, 43(3), 249-267.

Juran, J.M. (1988). On planning for Quality. London: Collier Macmillan.

Kaluarachchi, K. (2010). Organizational culture and total quality management practices: A Sri Lankan case. The TQM Journal, 22(1), 41-55. http://dx.doi.org/10.1108/17542731011009612

Kaushik, P., Khanduja, D., Mittal, K., \& Jaglan, P. (2012).A case study. The TQM Journal, 24(1), 4-16. http://dx.doi.org/10.1108/17542731211191186

Kaynak, H. (2003). The relationship between total quality management practices and their effects on firm performance. Journal of Operations Management, 21(4), 405-435. http://dx.doi.org/10.1016/s0272-6963(03)00004-4

Kim, J. O. \& Kohout, F. J. (1975). Multiple regression analysis: Subprogram regression. Statistical Package for the Social Sciences, 2, 320-342.

Klingenberg, B., Timberlake, R., Geurts, T., \& Brown, R. (2013). The relationship of operational innovation and financial performance-A critical perspective. International Journal of Production Economics, 142(2), 317-323. http://dx.doi.org/10.1016/j.ijpe.2012.12.001

Koontz, H., \& O'Donnell, C. (1968). Principles of management (1st ed.). New York: McGraw-Hill.

Krumwiede, K. R. \& Charles, S. L. (2006). Finding the right mix how to match strategy and management practices to enhance firm performance. Strategic Finance, 87, 37-43.

Lakhal, L., Pasin, F., \& Limam, M. (2006). Quality management practices and their impact on performance. International Journal of Quality \& Reliability Management, 23(6), 625-646. Retrieved from http://dx.doi.org/10.1108/02656710610672461

Madi Bin Abdullah, M., Uli, J., \& José Tarí, J. (2008). The influence of soft factors on quality improvement and performance. The TQM Journal, 20(5), 436-452. http://dx.doi.org/10.1108/17542730810898412

Nguyen, P., \& Robinson, A. (2015). Continuous improvement in Vietnam: unique approaches for a unique culture. Journal of Asia Business Studies, 9(2), 195-211. http://dx.doi.org/10.1108/jabs-11-2014-0093

O'Mahony, K., \& Garavan, T. (2012). Implementing a quality management framework in a higher education organisation. Quality Assurance in Education, 20(2), 184-200. 
http://dx.doi.org/10.1108/09684881211219767

Osborne, J. W., \& Fitzpatrick, D. C. (2012). Replication Analysis in Exploratory Factor Analysis: What it is and why it makes your analysis better. Practical Assessment, Research \& Evaluation, 17(15). $\mathrm{http}: / /$ pareonline.net/getvn.asp? $\mathrm{v}=17 \& \mathrm{n}=15$

Pannirselvam, G., \& Ferguson, L. (2001). A study of the relationships between the Baldrige categories. International Journal of Quality \& Reliability Management, 18(1), 14-37. http://dx.doi.org/10.1108/02656710110364468

Phan, U., Nguyen, P., Mai, K., \& Le, T. (2015). Key Determinants of SMEs in Vietnam. Combining Quantitative and Qualitative Studies. Review of European Studies, 7(11). http://dx.doi.org/10.5539/res.v7n11p359

Pilkington, A. (1996). Manufacturing Methods: Lessons from the Japanese Motor Industry. Asia Pacific Business Review, 2(3), 163-166. http://dx.doi.org/10.1080/13602389600000009

Powell, T. C. (1995). Total Quality Management as Competitive Advantage: A Review and Empirical Study. Strategic Management Journal, 16, 15-37. http://dx.doi.org/10.1002/smj.4250160105

Rahim, A. R. A., \& Bask, M. S. N. (2003). Case study method for new product development in engineer-to-order organizations. Work study, 52(1), 25-36.

Rao, S., Solis, L., \& Raghunathan, T. (1999). A framework for international quality management research: Development and validation of a measurement instrument. Total Quality Management, 10(7), 1047-1075. http://dx.doi.org/10.1080/0954412997226

Rodgers, J. L. \& Nicewander, W. A. (1988). Thirteen Ways to Look at the Correlation Coefficient. The American Statistician, 42(1), 59-66. http://dx.doi.org/10.1080/00031305.1988.10475524

Rosli, M. M. (2012). Competitive Strategy of Malaysian Small and Medium Enterprises: An Exploratory Investigation. American International Journal of Contemporary Research, 2(1), 93-105.

Samson, D., \& Terziovski, M. (1999). The Relationship Between Total Quality Management Practices and Operational Performance. Journal of Operations Management, 17, 393-409. http://dx.doi.org/10.1016/S0272-6963(98)

Saraph, J., Benson, P., \& Schroeder, R. (1989). An Instrument for Measuring the Critical Factors of Quality Management. Decision Sciences, 20(4), 810-829. http://dx.doi.org/10.1111/j.1540-5915.1989.tb01421.x

Seth, D., \& Tripathi, D. (2005). Relationship between TQM and TPM implementation factors and business performance of manufacturing industry in Indian context. International Journal Of Quality \& Reliability Management, 22(3), 256-277. http://dx.doi.org/10.1108/02656710510582480

Sila, I., \& Ebrahimpour, M. (2005). Critical linkages among TQM factors and business results. International Journal of Operations \& Production Management, 25(11), 1123-1155. http://dx.doi.org/10.1108/01443570510626925

Simons, H. (2009). Case study research in practice. Sage Publications, London.

Tavakol, M., \& Dennick, R. (2011). Making Sense of Cronbach's Alpha. International Journal of Medical Education, 2, 53-55.

Voss, C., Tsikriktsid, N., \& Frohlich, M. (2002). Case research in operations management. International Journal of Operations \& Production Management, 22(2), 195-219.

Watanabe, S. (2003). Vietnamese enterprises \& global competition - A Survival Guide. Vietnam Chamber of Commerce and Industry.

Wilson, D., \& Collier, D. (2000). An Empirical Investigation of the Malcolm Baldrige National Quality Award Causal Model. Decision Sciences, 31(2), 361-383. http://dx.doi.org/10.1111/j.1540-5915.2000.tb01627.x

Yin, R. (2003). Case study research: Design and method (3rd ed.). Thousand Oaks, CA: Sage.

Yong, A. G., \& Pearce, S. (2013). A Beginner's Guide to Factor Analysis: Focusing on Exploratory Factor Analysis. Tutorials in Quantitative Methods for Psychology, 9(2), 79-94. 


\section{Apendix A}

\section{Questionnaire Table (Survey Form)}

I am researching a survey related to the research topic:

Recommendations for improving quality management to increase organizational performance: A case study in Victory Joint Stock Company.

To complete it, I need the help from you to answer the questionnaire below. One questionnaire done is a further step for the process of finalizing the thesis. Thank you for participating in this survey.

All your answers and information providing will be safe in security and it only could be used to support to this research.

\begin{tabular}{|c|c|c|c|c|c|}
\hline \multicolumn{6}{|l|}{ QUESTIONNAIRE for MANAGERS } \\
\hline \multirow{2}{*}{\multicolumn{6}{|c|}{$\begin{array}{l}\text { 1. How long have you been working at Victory LLC? } \\
\text { 2. What is your position in the company? }\end{array}$}} \\
\hline & & & & & \\
\hline ORGANIZATIONAL PERFORMANCE & $\begin{array}{l}1-\text { Strongly } \\
\text { agree }\end{array}$ & $\begin{array}{c}2- \\
\text { Agree }\end{array}$ & $\begin{array}{c}3- \\
\text { Neutral }\end{array}$ & $\begin{array}{c}4- \\
\text { Disagree }\end{array}$ & $\begin{array}{l}5 \text { - Strongly } \\
\text { disagree }\end{array}$ \\
\hline \multicolumn{6}{|l|}{$\begin{array}{l}\text { 3. Efficient communication is taken place inside (leadership } \\
\text { and employees) and outside (company and customers) of } \\
\text { the organization. }\end{array}$} \\
\hline \multicolumn{6}{|l|}{ 4. The organization has the ability to compete over its rivals. } \\
\hline \multicolumn{6}{|l|}{$\begin{array}{l}\text { 5. The organization offers transparent sales plan and } \\
\text { long-term development policy. }\end{array}$} \\
\hline \multicolumn{6}{|l|}{ 6. The organization provides high quality products. } \\
\hline \multicolumn{6}{|l|}{$\begin{array}{l}\text { 7. The organization is received high satisfaction from } \\
\text { customers. }\end{array}$} \\
\hline LEADERSHIP & $\begin{array}{l}1-\text { Strongly } \\
\text { agree }\end{array}$ & $\begin{array}{c}2- \\
\text { Agree }\end{array}$ & $\begin{array}{c}3- \\
\text { Neutral }\end{array}$ & $\begin{array}{c}4- \\
\text { Disagree }\end{array}$ & $\begin{array}{l}5 \text { - Strongly } \\
\text { disagree }\end{array}$ \\
\hline \multicolumn{6}{|l|}{$\begin{array}{l}\text { 8. A manager communicates the company's philosophy to } \\
\text { the employees. }\end{array}$} \\
\hline \multicolumn{6}{|l|}{$\begin{array}{l}\text { 9. A manager actively develops one integrated quality plan to } \\
\text { meet business objectives. }\end{array}$} \\
\hline \multicolumn{6}{|l|}{$\begin{array}{l}\text { 10. A manager strongly encourages employee involvement in } \\
\text { quality management and improvement activities. }\end{array}$} \\
\hline \multicolumn{6}{|l|}{$\begin{array}{l}\text { 11. A manager arranges adequate resources for employee } \\
\text { education and training. }\end{array}$} \\
\hline STRATEGIC PLANNING & $\begin{array}{l}1-\text { Strongly } \\
\text { agree }\end{array}$ & $\begin{array}{c}2- \\
\text { Agree }\end{array}$ & $\begin{array}{c}3- \\
\text { Neutral }\end{array}$ & $\begin{array}{c}4- \\
\text { Disagree }\end{array}$ & $\begin{array}{l}5 \text { - Strongly } \\
\text { disagree }\end{array}$ \\
\hline \multicolumn{6}{|l|}{ 12. The company's mission has a clear focus on quality. } \\
\hline \multicolumn{6}{|l|}{$\begin{array}{l}\text { 13. A manager allocates sufficient resources for the successful } \\
\text { implementation of strategies focused on quality. }\end{array}$} \\
\hline \multicolumn{6}{|l|}{$\begin{array}{l}\text { 14. A manager directs resources to the requirements and needs } \\
\text { of our customers and employees. }\end{array}$} \\
\hline \multicolumn{6}{|l|}{$\begin{array}{l}\text { 15. At each level of the company, teams are assigned to set } \\
\text { objectives and devise action plans. }\end{array}$} \\
\hline \multicolumn{6}{|l|}{$\begin{array}{l}\text { 16. A manager has an overall action plan measurement system } \\
\text { that covers all key deployment areas and stakeholders. }\end{array}$} \\
\hline PROCESS MANAGEMNT & $\begin{array}{l}1-\text { Strongly } \\
\text { agree }\end{array}$ & $\begin{array}{c}2- \\
\text { Agree }\end{array}$ & $\begin{array}{c}3- \\
\text { Neutral }\end{array}$ & $\begin{array}{c}4- \\
\text { Disagree }\end{array}$ & $\begin{array}{l}5 \text { - Strongly } \\
\text { disagree }\end{array}$ \\
\hline \multicolumn{6}{|l|}{ 17. Inspection, review or checking of work is automated. } \\
\hline \multicolumn{6}{|l|}{ 18. Production schedule/work distribution is stable. } \\
\hline \multicolumn{6}{|l|}{ 19. The production process is automated. } \\
\hline \multicolumn{6}{|l|}{$\begin{array}{l}\text { 20. Production processes are designed to minimize the } \\
\text { chances of employee errors. }\end{array}$} \\
\hline 21. Clarity of work or process instructions given to employees & & & & & \\
\hline
\end{tabular}

This is the end of the survey - Thank you for your support 


\begin{tabular}{|c|c|c|c|c|c|}
\hline \multicolumn{6}{|l|}{ QUESTIONNAIRE for STAFF } \\
\hline $\begin{array}{l}\text { 1. How long have you been working at Victory LLC? } \\
\text { 2. What is your position in the company? }\end{array}$ & \multicolumn{5}{|c|}{ _ years } \\
\hline ORGANIZATIONAL PERFORMANCE & $\begin{array}{l}1-\text { Strongly } \\
\text { agree }\end{array}$ & $\begin{array}{c}2- \\
\text { Agree }\end{array}$ & $\begin{array}{c}3- \\
\text { Neutral }\end{array}$ & $\begin{array}{c}4 \text { - } \\
\text { Disagree }\end{array}$ & $\begin{array}{l}5 \text { - Strongly } \\
\text { disagree }\end{array}$ \\
\hline $\begin{array}{l}\text { 3. Efficient communication is taken place inside } \\
\text { (leadership and employees) and outside (company and } \\
\text { customers) of the organization. }\end{array}$ & & & & & \\
\hline $\begin{array}{l}\text { 4. The organization has the ability to compete over its } \\
\text { rivals. }\end{array}$ & & & & & \\
\hline $\begin{array}{l}\text { 5. The organization offers transparent sales plan and } \\
\text { long-term development policy. }\end{array}$ & & & & & \\
\hline 6. The organization provides high quality products. & & & & & \\
\hline $\begin{array}{l}\text { 7. The organization is received high satisfaction from } \\
\text { customers. }\end{array}$ & & & & & \\
\hline HUMAN RESOURCE MANAGEMENT & $\begin{array}{l}1-\text { Strongly } \\
\text { agree }\end{array}$ & $\begin{array}{c}2- \\
\text { Agree }\end{array}$ & $\begin{array}{c}3- \\
\text { Neutral }\end{array}$ & $\begin{array}{c}4- \\
\text { Disagree }\end{array}$ & $\begin{array}{l}5 \text { - Strongly } \\
\text { disagree }\end{array}$ \\
\hline 8. I am received continuous training. & & & & & \\
\hline $\begin{array}{l}\text { 9. I am measured about my satisfaction with training } \\
\text { received. }\end{array}$ & & & & & \\
\hline 10. I am encouraged to be totally quality involved. & & & & & \\
\hline 11. I can participate in achieving organizational objectives. & & & & & \\
\hline $\begin{array}{l}\text { 12. I am responsible for the tasks I perform, and inspect my } \\
\text { own work. }\end{array}$ & & & & & \\
\hline
\end{tabular}

This is the end of the survey - Thank you for your support

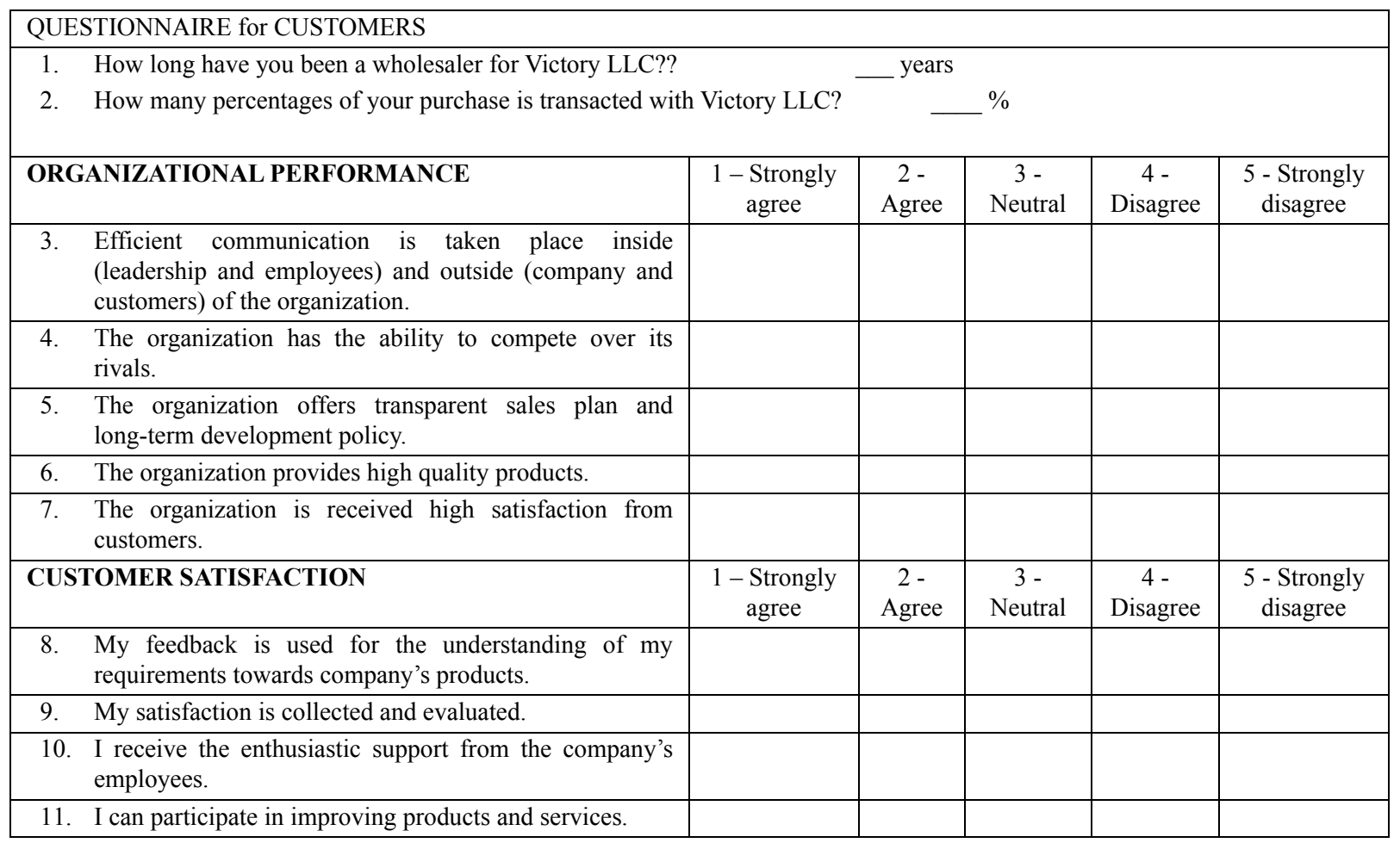

This is the end of the survey - Thank you for your support 


\section{Apendix B}

\section{SPSS analysis detailed results}

\section{Exploratory factor analysis of Human Resource Management factor}

KMO and Bartlett's Test

\begin{tabular}{ccc}
\hline \multicolumn{2}{c}{ Kaiser-Meyer-Olkin Measure of Sampling Adequacy. } & .762 \\
\hline \multirow{2}{*}{ Bartlett's Test of Sphericity } & Approx. Chi-Square & 82.469 \\
& df & 10 \\
\hline
\end{tabular}

\begin{tabular}{lcc}
\hline Communalities & & \\
\hline & Initial & Extraction \\
\hline HR1 & 1.000 & .401 \\
HR2 & 1.000 & .765 \\
HR3 & 1.000 & .597 \\
HR4 & 1.000 & .669 \\
HR5 & 1.000 & .581
\end{tabular}

Extraction Method: Principal Component Analysis.

Total Variance Explained

\begin{tabular}{ccccccc}
\hline \multirow{2}{*}{ Component } & \multicolumn{3}{c}{ Initial Eigenvalues } & \multicolumn{2}{c}{ Extraction Sums of Squared Loadings } \\
\cline { 2 - 6 } & Total & \% of Variance & Cumulative \% & Total & \% of Variance & Cumulative \% \\
\hline 1 & 3.014 & 60.275 & 60.275 & 3.014 & 60.275 & 60.275 \\
2 & .754 & 15.078 & 75.353 & & & \\
3 & .568 & 11.368 & 86.721 & & & \\
4 & .471 & 9.417 & 96.138 & & & \\
5 & .193 & 3.862 & 100.000 & & & \\
\hline
\end{tabular}

Extraction Method: Principal Component Analysis.

Component Matrix ${ }^{\mathrm{a}}$

\begin{tabular}{cc}
\hline & Component \\
\cline { 2 - 2 } & 1 \\
\hline HR2 & .875 \\
HR4 & .818 \\
HR3 & .773 \\
HR5 & .762 \\
HR1 & .634
\end{tabular}

Extraction Method: Principal Component Analysis.

a. 1 components extracted

\section{Exploratory factor analysis of Customer Satisfaction factor}

KMO and Bartlett's Test

\begin{tabular}{|c|c|c|}
\hline \multicolumn{3}{|c|}{ Kaiser-Meyer-Olkin Measure of Sampling Adequacy. } \\
\hline \multicolumn{2}{|c|}{ Bartlett's Test of Sphericity } & $\begin{array}{c}\text { Approx. Chi-Square } \\
\text { df }\end{array}$ \\
\hline \multicolumn{3}{|c|}{ Communalities } \\
\hline & Initial & Extraction \\
\hline CS1 & 1.000 & .796 \\
\hline CS2 & 1.000 & .795 \\
\hline CS3 & 1.000 & .781 \\
\hline CS4 & 1.000 & .653 \\
\hline
\end{tabular}

Extraction Method: Principal Component Analysis.

Total Variance Explained

\begin{tabular}{ccccccc}
\hline \multirow{2}{*}{ Component } & \multicolumn{3}{c}{ Initial Eigenvalues } & \multicolumn{3}{c}{ Extraction Sums of Squared Loadings } \\
\cline { 2 - 6 } & Total & \% of Variance & Cumulative $\%$ & Total & $\%$ of Variance & Cumulative \% \\
\hline 1 & 3.025 & 75.623 & 75.623 & 3.025 & 75.623 & 75.623 \\
2 & .637 & 15.936 & 91.560 & & &
\end{tabular}




\begin{tabular}{cccc}
3 & .236 & 5.891 & 97.450 \\
4 & .102 & 2.550 & 100.000 \\
\hline
\end{tabular}

Extraction Method: Principal Component Analysis.

Component Matrix ${ }^{\mathrm{a}}$

\begin{tabular}{lc}
\hline & Component \\
\cline { 2 - 3 } & 1 \\
\hline CS1 & .892 \\
CS2 & .892 \\
CS3 & .884 \\
CS4 & .808 \\
\hline
\end{tabular}

Extraction Method: Principal Component Analysis.

a. 1 components extracted.

\section{Correlations of Manager related factors}

Correlations

\begin{tabular}{|c|c|c|c|c|c|}
\hline & & OP-Manager & LD & ST & PM \\
\hline \multirow{3}{*}{ OP-Manager } & Pearson Correlation & 1 & .754 & $.985^{*}$ & .734 \\
\hline & Sig. (2-tailed) & & .246 & .015 & .266 \\
\hline & $\mathrm{N}$ & 4 & 4 & 4 & 4 \\
\hline \multirow{3}{*}{ LD } & Pearson Correlation & .754 & 1 & .774 & .830 \\
\hline & Sig. (2-tailed) & .246 & & .226 & .170 \\
\hline & $\mathrm{N}$ & 4 & 4 & 4 & 4 \\
\hline \multirow{3}{*}{ ST } & Pearson Correlation & $.985^{*}$ & .774 & 1 & .831 \\
\hline & Sig. (2-tailed) & .015 & .226 & & .169 \\
\hline & $\mathrm{N}$ & 4 & 4 & 4 & 4 \\
\hline \multirow{3}{*}{ PM } & Pearson Correlation & .734 & .830 & .831 & 1 \\
\hline & Sig. (2-tailed) & .266 & .170 & .169 & \\
\hline & $\mathrm{N}$ & 4 & 4 & 4 & 4 \\
\hline
\end{tabular}

*. Correlation is significant at the 0.05 level (2-tailed).

\section{Correlations of Staff related factors}

Correlations

\begin{tabular}{cccc}
\hline & & OP-Staff & HRM \\
\hline \multirow{3}{*}{ OP-Staff } & Pearson Correlation & 1 & $.766^{* *}$ \\
& Sig. (2-tailed) & & .000 \\
& $\mathrm{~N}$ & 42 & 42 \\
\multirow{2}{*}{ HRM } & Pearson Correlation & $.766^{* *}$ & 1 \\
& Sig. (2-tailed) & .000 & \\
& $\mathrm{~N}$ & 42 & 42 \\
\hline
\end{tabular}

**. Correlation is significant at the 0.01 level (2-tailed).

\section{Correlations of Customer related factors}

Correlations

\begin{tabular}{cccc}
\hline & & OP-Customer & CS \\
\hline \multirow{2}{*}{ OP-Customer } & Pearson Correlation & $\mathbf{1}$ & $\mathbf{. 6 5 2}^{*}$ \\
& Sig. (2-tailed) & & $\mathbf{. 0 4 1}$ \\
& N & $\mathbf{1 0}$ & $\mathbf{1 0}$ \\
CS & Pearson Correlation & $\mathbf{. 6 5 2}^{*}$ & $\mathbf{1}$ \\
& Sig. (2-tailed) & $\mathbf{. 0 4 1}$ & \\
& N & $\mathbf{1 0}$ & $\mathbf{1 0}$
\end{tabular}

*. Correlation is significant at the 0.05 level (2-tailed).

\section{Copyrights}

Copyright for this article is retained by the author(s), with first publication rights granted to the journal.

This is an open-access article distributed under the terms and conditions of the Creative Commons Attribution license (http://creativecommons.org/licenses/by/4.0/). 